\author{
Kemal SAYLAN \\ Doç. Dr.| Assoc. Prof. Dr. \\ Gümüşhane Üniversitesi, Edebiyat Fakültesi, Tarih Bölümü, Gümüşhane, TR \\ Gümüşhane University, Faculty of Arts, Department of History, Gümüşhane, TR \\ ORCID: 0000-0001-6493-7001 \\ kemalsaylan52@gmail.com
}

\title{
Gümüşhane'deki Osmanlı Dönemi Eserleri: Sultan Süleyman Han Cami ve Çevresindeki Yapılara Dair*
}

\section{Öz}

Sultan Süleyman Han Cami'nin yapım tarihi kesin olarak bilinmese de Kanuni Sultan Süleyman döneminde yapıldığı kabul edilmektedir. Cami ve çevresindeki yapılarla birlikte kasaba merkezinde küçük bir külliye mahiyetindedir. Yapıların merkezinde Kanuni Sultan Süleyman Han (Cami-i Kebir) Cami bulunmaktadır. Diğer yapılar ise caminin etrafında şekillenmiştir. Caminin çevresinde farklı tarihlerde türbe, hazire, çeşme, kütüphane, medrese ve vakıf binaları inşa edilmiştir. Ancak bu yapılardan bir bölümü günümüze ulaşamamıştır. Günümüze kalabilen yapılar cami, türbe, hazire ve çeşmeden ibarettir.

Sultan Süleyman Han Cami, Gümüşhane Kasabası'nın kuruluşu, gelişimi ve tarihi açısından büyük önem taşımaktadır. Bölgedeki gümüş madenlerinin ekonomik değerinin artmasıyla birlikte kasaba gelişmiş ve kasaba merkezinde bir cami inşa edilmiştir. Kasaba nüfusun artması üzerine Türk şehir yapısına uygun olarak caminin çevresinde yeni evlerin ve çarşının inşa edilmesiyle de Gümüşhane Kasabası idari bir merkez halini almıştır. 19. yüzyıldan itibaren de Osmanlı taşra teşkilatında Trabzon Vilayeti'ne bağlı bir sancak merkezi olmuştur.

Gümüşhane Kasabası bugün terkedilmiş bir şehir görünümündedir. Kasaba, 19. yüzyılın ikinci yarısından itibaren Harşit Vadisi'ne kaymaya başlamıştır. Bölge, Günümüzde Gümüşhane şehrinin bir mahallesi konumundadır ve Süleymaniye adıyla anılmaktadır. Bölgede ayakta kalabilen en önemli yapı ise Sultan Süleyman Han Cami (Cami-i Kebir)'dir.

Çalışmada Başbakanlık Osmanlı Arşivi'nde yer alan kayıtlardan hareketle cami ve çevresindeki yapıların Osmanlı dönemindeki fonksiyonları konu edilecek, ayrıca bu yapıların günümüzdeki durumlarına değinilecektir. Böylece günümüzde kaybolmaya yüz tutmuş olan bu yapıların değeri ve önemi ortaya çıarılmaya çalışılacaktır.

Anahtar Kelimeler: Gümüşhane, Sultan Süleyman Han, Cami, Kütüphane, Vakıf.

* Bu çalışma 17.F1210.02.01 nolu Gümüşhane Üniversitesi Bap Projesi kapsamında hazırlanmış olup 2426 Nisan 2018 tarihleri arasında Trabzon'da düzenlenen I. Uluslararası Kanuni Sultan Süleyman Sempozyumu'nda sunulan "Gümüşhane'de Osmanlı Dönemi Eserleri: Sultan Süleyman Han Külliyesi” adlı özet bildirinin genişletilmiş halidir. 


\title{
Ottoman Period Pieces in Gumushane: On the Sultan Suleyman Han Mosque and Their Environment
}

\begin{abstract}
It is accepted that the construction date of the Sultan Süleyman Han Mosque was made during the reign of Sultan Suleyman the Magnificent. It is a small complex in the town center with the mosque and surrounding structures. Kanuni Sultan Suleyman Han (Cami-i Kebir) Mosque is located at the center of the constructions. Other constructions are formed around the mosque. In different dates around the Camin, tombs, haziras, fountains, libraries, madrasa and foundation buildings were constructed. However, some of these structures have not survived. The buildings that can manage to survive are the mosque, the tomb, the treasure and the fountain.
\end{abstract}

Sultan Suleyman Han Mosque is of great importance for the establishment, development and history of Gumushane Town. As the economic value of the silver mines in the region increased, the town developed and a mosque was built in the town center. On the increase of the population of the town, Gumushane Town became an administrative center by constructing new houses and bazaar around the mosque in accordance with the Turkish city structure. From the 19th century, it became a sanjak center connected to Trabzon Province in the Ottoman provincial organization. Gumushane Town is a deserted city today. From the second half of the 19th century, the town began to slip into the Harshit Valley. Today, the region is a neighborhood of the city of Gumushane and is known as Suleymaniye. The most important structure that can survive in the region is the Sultan Suleyman Han Mosque (Cami-i Kebir).

In the present study, the functions of the mosque and its surrounding structures in the Ottoman period will be discussed with reference to the records in the Ottoman Archives of the Prime Ministry and the present situation of these structures will be mentioned. Thus, it will be tried to reveal the value and importance of these structures that have been disappearing today.

Keywords: Gumushane, Sultan Suleyman Han, Mosque, Library, Foundation.

\section{Giriş}

Gümüşhane Kasabası'nın ilk kurulduğu yer olarak kabul edilen bölge günümüzde Gümüşhane Şehri’nin bir mahallesidir ve Kanuni Sultan Süleyman’a atfen Süleymaniye olarak anılmaktadır. Bazı yerel kaynaklarda kasaba tarihinin milattan öncelere kadar uzandığı ifade edilmektedir (Cumhuriyetin 75. Yı11: 40; San 1991: 119; Üçüncüoğlu Trhsz, 45, 54; Karpuz 1991: 155; Uslu 1980: 4; Yüksel 1997: 21). Ancak günümüzde bu ifadeyi destekleyen herhangi somut bir belgeye şu ana kadar ulaşılmış değildir. Osmanlı öncesi yazılı kayıtlarına bakıldı̆̆ında bu bölgede Osmanlı öncesi herhangi bir şehir ya da idari birime rastlanmadığı görülmektedir. ${ }^{1} \mathrm{Bu}$ bilgiden hareketle kasabanın Osmanlı döneminde kurularak geliştiğini söylemek mümkündür. Bu durumla ilgili Cumhuriyetin 50. Yılında Gümüşhane adıyla yayınlanan 1973 il

\footnotetext{
${ }^{1}$ Örneğin, MÖ 400'lü yıllarda Ksenephon'un kaleme aldığı Onbinlerin Dönüşü adlı kitapta Süleymaniye veya çevresinde yer alan her hangi bir birimden bahsetmediği görülmektedir. Yine 1294 yılında bölgeden geçtiği iddia edilen Marko Polo, 1404 senesinde İspanyol kralı tarafından Timur'a hediyeler sunmak için gönderilen Gümüşhane'den geçen Ruy Gonzales de Clavijo da bölgeden geçerken yöredeki yerleşim birimlerinin isimlerini vermiş ancak Gümüşhane'ye dair herhangi bir bilgi vermemektedir (Saylan 2016: 68-69).
} 
yıllığında Kanuni Sultan Süleyman'ın “tarihten beri gümüş madenleriyle ünlü Gümüşhane bölgesinin imarını emretmesi üzerine bugünkü Süleymaniye çevresinde maden ocaklarında çalışanlar için çok sayıda ev inşa edildiğini ve bölgeye bir de cami yapılarak şehrin gelişmeye başladığı" ifade edilmektedir (GIYY 1973: 1). Fakat bu bilginin doğruluğunu da Başbakanlık Osmanlı Arşivi'nde tasnifte bulunan mevcut kaynaklardan teyit etmek mümkün değildir. Yani Gümüşhane’nin bir Osmanlı Kasabası olduğunu kabul etmekle birlikte kaç tarihlerinde, hangi padişah döneminde kurulduğunu ve gelişmeye başladığını tam olarak tespit etmek mevcut kaynaklardan hareketle mümkün gözükmemektedir. Bununla birlikte eldeki mevcut bilgilerden hareketle şöyle bir yorum yapmak mümkündür. Kanuni Sultan Süleyman döneminde Gümüşhane bölgesinde bulunan Hazine, Mağara ve Kırkpavli madenlerine yakın mevkide bir cami yaptırılmıştır. Daha sonra yörede yeni gümüş madeni ocaklarının açılmasıyla bölgeye madenlerde çalışacak işçiler aileleriyle birlikte yerleşmeye başlamıştır. Bölgedeki nüfusun artması üzerine Türk şehir yapısına uygun olarak caminin çevresinde yeni evler ve çarşı inşa edilmiştir. ${ }^{2}$ Böylece Gümüşhane Kasabası gelişmeye başlamıştır. Zamanla gelişen kasaba, 16. yüzyılda bir ara Erzurum Beylerbeyiliği’ne bağlanmışsa da (Bostan 2002: 232) 19. yüzyıldan itibaren Osmanlı idari teşkilatında Trabzon Vilayeti'ne bağlı bir sancak merkezi olarak yerini almıştır (Saylan 2014: 26-27).

Gümüşhane Kasabası, bugün terkedilmiş bir şehir görünümündedir. 19. yüzyılın ikinci yarısından itibaren kasaba çevresindeki madenlerin ekonomik değerini yitirmesi ve Trabzon-Erzurum Yolu'nun Harşit Irmağı'nın kenarında inşa edilmesi gibi nedenlerden dolayı şehir Harşit Vadisi'ne kaymıştır (Saylan 2016: 67-74). Bütün bu bilgiler ve yorumlar şehrin kuruluşunda Sultan Süleyman Cami’nin önemini ortaya koymaktadır. Bu cami, kuşkusuz şehrin en eski yapılarından biridir. Günümüzde dahi kasabadan geriye kalan ve yıkılmadan ayakta durabilen yegâne eserlerinden biridir. Kasabanın merkezinde yer alan caminin bulunduğu mahalle de kasabanın en önemli ve en büyük mahallesi olmuştur. 19. yüzyıl arşiv vesikalarında mahallenin adı Cami-i Kebir olarak geçmektedir. Mahallede, 20. yüzyılın başlarında Sultan Süleyman Han Cami'nin yanı sıra büyük hanlar, hamamların yanı sıra 2 fırın, 16 dükkân, 2 kasap, 1 kalaycı, 1 sobacı, 1 purut (küp, güveç, kiremit yapan esnaf), 1 berber, 1 terzi ve 3 adet kahvehane bulunduğu bilinmektedir (San 1991: 121).

\footnotetext{
${ }^{2}$ Camilerin özellikle de Ulu Camilerin şehrin mahalle ve yerleşim planının oluşmasındaki önemi için bkz. (Faroqhi 2011); (Ergenç 1995); (Ergenç 2013); (Düzbakar 2003: 97-108).
} 
16. yüzyılın ilk yarısında inşa edildiği tahmin edilen Süleyman Han Cami’nin çevresine farklı tarihlerde türbe, hazire, çeşme, kütüphane, medrese ve vakıf binaları inşa edilmiştir. ${ }^{3}$ Böylece 19. yüzyıla gelindiğinde bu yapılar, kasaba merkezinde küçük bir külliye mahiyetini arz etmeye başlamıştır. Ancak bu yapılardan bir bölümü günümüze ulaşamamıştır. Günümüze kalabilen yapılar cami, türbe, hazire ve çeşmeden ibarettir.

Bu çalışmada Gümüşhane şehrinin kuruluşunda ve gelişiminde önemli bir rolü bulunduğunu düşündüğümüz Sultan Süleyman Han Cami'nin Cumhurbaşkanlığı'na bağlı Osmanlı Arşivi vesikalarından hareketle 19. yüzyıldaki durumu hakkında bilgi verilmesi amaçlanmaktadır. Böylece günümüzde değeri ve önemi hakkında çok az bilgiye sahip olunan bu yapının tarihi süreç içindeki gelişimi hakkında kısmen de olsa bilgi edinileceği düşünülmektedir. Ayrıca günümüzde varlığı dahi bilinmeyen fakat camiyle ilgisi bulunan vakıf, kütüphane gibi yapıların yeniden ayağa kaldırılması için bir farkındalık oluşturulması hedeflenmektedir.

\section{Sultan Süleyman Han Cami ve Çevresindeki Yapılar}

Yukarıda da ifade ettiğimiz gibi 16. yüzyılın ilk yarısında inşa edildiği tahmin edilen Süleyman Han Cami’nin etrafına farklı tarihlerde çeşitli yapıların da eklenmesiyle bu yapılar 19. yüzyıldan itibaren kasaba merkezinde küçük bir külliye mahiyetini arz etmeye başlamıştır. Bu yapılar şunlardır: Süleyman Han Cami, haziresi, medresesi, kütüphanesi ve çeşmesi ile Hacı Tahir Efendi Türbesi'dir.

\section{1- Sultan Süleyman Han Cami}

19. yüzyıl arşiv kaynaklarında caminin adı kahır ekseriyetle Sultan Süleyman Han Cami olarak belirtilmektedir. Ancak bazı vesikalarda Cami-i Kebir adiyla anılmaktadır. Günümüzde halk arasında caminin adı Süleymaniye Cami ya da Ulu Cami olarak bilinmektedir.

Üzerinde kitabesi ve vakfiyesi bulunmayan Sultan Süleyman Han Cami’nin yapım tarihi tam olarak bilinmemektedir. Ancak caminin Kanuni Sultan Süleyman döneminde yaptırıldığı kabul edilmektedir. Halk arasında caminin Kanuni Sultan Süleyman'ın İran Seferi sırasında yöreden geçerken gümüş madenlerinin çıkarıldığı bu bölgede evlerin yapılmasını emretmesi üzerine inşaatına başlandığına inanılmaktadır.

\footnotetext{
${ }^{3}$ Bugün caminin girişinde yapım tarihi olarak Kanuni Sultan Süleyman’ın saltanat tarihleri olan 15201566 tarihleri verilmektedir.
} 
Bazı kaynaklarda da bu bilgiden hareketle caminin ve şehrin Kanuni Sultan Süleyman'ın emriyle inşa edildiği belirtilmektedir (Uslu 1991: 151; Tuncel 1996: 275).

Cami, Erzurum, Kültür ve Tabiat Varlıklarını Koruma Bölge Kurulu'nun 24.09.1989 tarih ve 160 sayılı kararıyla tescil edilmiştir. 2016 tarihli Gümüşhane Kültür Envanterinde caminin düzgün dikdörtgen bir plan üzerine oturtulduğu, tamamen kaba yontma taştan inşa edildiği ifade edilmektedir. Caminin köşelerinde, pencere çevrelerinde, üst sınırını belirleyen kısımlarında, son cemaat yerinin yan cephesini belirleyen kısımlarda, bütün camiyi donatan ve yapıyı iki kat gibi gösteren kısımda ise dışa taşmış olarak bir sıra düzgün kesme taş kullanılmıştır. (GKE 2016: 29).

Caminin Batı cephesi yamaca dayanmaktadır. Bu nedenle alt sirada pencere bulunmamakta sadece üst sırada pençeler yer almaktadır. Güney cephede üstte üç, altta iki pencere olmak üzere toplam 5 pencere, doğu cephesinde ise altta ve üstte dörder olmak üzere toplam 8 pencere yer almaktadır.

Caminin orijinal ve dokunulmayan tek bölümü olan minaresi kesme taştan yapılmıştır. Minare, kare kaideli ve silindirik gövdelidir. Güneydoğu köşesine doğu duvarına bitişik olarak inşa edilmiş minarede kaidenin doğusundan açılan bir giriş kapısı bulunmaktadir.

Caminin kuzeyinde iki kat şeklinde düzenlenmiş son cemaat yeri mevcuttur. Son cemaat yerinin üst kat dış mahfiline, mekânın dışından başlayan ve batı duvarına içten bitişik olan merdivenle çıkılmaktadır. Giriş kapısının bulunduğu kuzey cephesinde caminin içerisindeki iç mahfile açılan ve basık yuvarlak kemerli girişte kesme taştan örülmüş ikinci bir kapı bulunmaktadır. Her iki girişin yanlarında birer pencere vardır. Caminin içinde düz ahşap tavan yer almaktadır. İki sırada taş kaideli ikişer ahşap sütunla taşınan üst örtü, duvarlara bitişik ahşap sütunlarla desteklenmiştir. Ahşap taşıyıcılar birbirine basık yuvarlak kemerlerle bağlıdır. Mihrap ise kesme taştan yapılmıştır. Mihrabın üzerinde 1901 senesinde Salih adında bir hattat tarafından yazıldığ 1900 tarihli olan kıblegâhlar yer almaktadır (Yurttaş 2007: 61-62).

Günümüzdeki durumu yukarıda ifade edildiği gibi olan camiyle ilgili Başbakanlık Osmanlı Arşivi'nde çok sayıda kayıt bulunmaktadır. Bu kayıtların büyük bir bölümü caminin 19. yüzyıldaki durumuyla ilgilidir. Elimizdeki kayıtlarda camide görev yapanlara ve caminin tamirine dair bilgiler bulunmaktadır. 


\section{a. Camide Görev Alanlar}

Arşiv kayıtlarına bakıldığında 19. yüzyılın sonlarında Sultan Süleyman Han Cami’nde imam-1 evvel, imam-1 sani, hitabet, müezzin, müezzin-i molla, fetihhan, muarrifan, aşırhan, devirhan, ser-mahfel aşırhan, Cuma vaizi, şeyh-ül kurra, ferraş, suyolculuk, hafızküttaplık, tevliyet ve kayyum gibi görevlilerin bulunduğu anlaşılmaktadır (BOA, Y. MTV: 107/24; BOA, EV. BRT: 158/21; BOC, E. EV: 13/1524 vd). Konuyla ilgili Ocak 1887 tarihinde Gümüşhane Mutasarrıflığı İdare Meclisi tarafından Trabzon Vilayeti'ne gönderilen mazbatada bu görevlilerden bazılarının aldıkları ücretler şu şekilde belirtilmiştir:

- İmam evi bulunan Haci Raşid Efendinin vazife-i seneviyesi 52 kuruş 10 para

- Boş bulunan imam-1 sanilik (ikinci imamlık) maaşı yevmi 24 akçe (8 kuruş)

- Hitabet maaşı vazife-i senevisi 16 kuruş

- Mü'ezzinlik maaşı vazife-i senevisi 49 kuruş

- Diğer mü'ezzinlik maaşı yevmi 10 akçe

- Mü’ezzin-i molla ve fetihhan ve muarrifân (tarif edici) maaşları yevmi 50 akçe

- Aşırhan ve devirhan maaşları yevmi 52 akçe

- Ser-mahfel aşırhan maaşı vazife-i senevisi 21 kuruş

- Sülüs hisse Cum'a vaizlik maaşı senevisi 33 kuruş 30 para, diğer hissenin vazife-i senevisi 11 kuruş 30 para

- Nısf hisse müderrislik maaşı vazife-i senevisi 32 kuruş 20 para

- Şeyhü'l-kuralık maaşı vazife-i senevisi 48 kuruş 20 para

- Ferraş (süpürgeci) ve kayyumluk (cami hademesi) maaşı vazife-i senevisi 8 kuruş 20 para

- Tevliyet maaşı vazife-i senevisi 11 kuruş

Görevlilerin aldıkları ücretlerin toplamının 260 küsur kuruşa denk geldiğinin belirtildiği bu yazıda; beratların yenilenememesi, caminin vilayet dâhilinde herhangi bir gelirinin ve vakfının bulunmaması gibi sebeplerden dolayı camide görev yapan kişilerin bu ücretlerle görevlerini layıkıyla yerine getiremedikleri ifade edilmektedir. Bu nedenle camideki görevlilerin maaşlarının

- İmam-1 evvellik maaşının 200 kuruş

- İmam-1 sanilik maaşının 250 kuruş

- Hitabet maaşının yıllıktan aylığa çevrilerek aylığının 100 kuruş

- Müezzinlik maaşının aylığa çevrilerek aylık 150 kuruş 
- Fetihhan, devirhan, marufhan ve salâhân maaşlarının aylık 75 kuruş

- Şeyhü'l-kurralık maaşının aylık 150 kuruş

- Ser-mahfel-i aşırhan maaşının aylık 40 kuruş

- Farraş ve kayyumluk maaşlarının aylık 130 kuruş

- Müderrislik ve vaizlik maaşlarının aylık 200 kuruş

olmak üzere toplam aylıklarının 1.145 kuruş olması talep edilmektedir. Trabzon Vilayeti'ne gönderilen bu yazı Evkaf-ı Hümayun Nezareti'ne havale edilmiştir (BOA, Y. MTV: 107/24). Ancak bu talebe ilişkin Evkaf-1 Hümayun Nezareti’nden herhangi bir cevap gelmediği anlaşılmaktadır. Bu nedenle Gümüşhane Mutasarrıflığı camide görev yapan bu kişilerin ücretlerini başka yollardan temin etmeye çalışmıştır. Bu durum da ezanların vakitsiz okunmasına, hatta camide imam-1 evvellik ve medresede müderrislik görevi yapmakta olan Hacı Raşid Efendi'nin geçimini sağlayamadığından, Kelkit Kazası'na bağlı Posus Köyü'nde ikamet etmek zorunda kalmasına neden olmuştur (BOA, Y. MTV: 107/24).

17. yüzyılın ikinci yarısından 19. yüzyılın ikinci yarısına kadar olan dönemdeki kayıtlar incelendiğinde camide görev alanların ücretlerinin Gümüşhane Mukataası emvalinden ödendiği anlaşılmaktadır (BOA, AE. SMST. III: 371/29425; BOA, EV. BRT: 14/7). Örneğin 1675 tarihinde camide fetihhanlı yapan Osman Efendi'nin bir senelik ücretini Gümüşhane Mukataası Emini Zülfikar Ağa karşılamıştır (BOA, AE. SMMD. IV: 19/2098). 1681 senesinde müezzin olarak camide görev yapan Osman Efendi'nin aylık 8 akçe olan ücreti (BOA, AE. SMMD. IV: 2/141) ve camide müezzin olarak görev yapan Molla Mehmed'in aylık 3 akçe olan maaşı (BOA, AE. SMMD. IV: 2/180) ile aylık sekiz akçe ulufe ile emekliye ayrılan Yeniçeri Cemaati'nden Hüseyin Süleyman Efendi'nin emeklilik ücretleri Gümüşhane Mukataası'ndan karşılanmıştır (BOA, AE. SMMD. IV: 2/184). 1682 tarihinde camide günlük 4 akçe ile devirhanlık yapan Mevlana Mehmed Halife bir y1llık ücretini Mukataa Emini Ömer Ağa'dan almıştır (BOA, AE. SABH. I: 352/24685). 1745 tarihinde camide müezzin olan Süleyman Efendi vazifesine ait beratı sureti ile bir yıllık alacağını Mukataa Emini elHac Abdurrahman Ağa'dan teslim almıştır (BOA, AE. SMHD. I: 247 20167). 1786 tarihinde camide vaiz olarak görev yapan Seyyid Mehmed 12 akçe olan alacağını Gümüşhane Mukataası'ndan tahsil etmiştir (BOA, AE. SABH. I: 252/16886).

Arşiv belgelerine bakıldığında camide görev yapan hizmetlilerin maaşlarının Gümüşhane Mukataası'nın yanı sıra bazen de boyahane ve ağnam mukataalarından karşılandığı anlaşılmaktadır. Örneğin 1675 senesinde camide aşırhan olarak görev 
yapan Molla Cuma Efendi bir senelik ücretini Boyahane Mukataası Emini Zülfikar Ağa'dan tahsil etmiştir (BOA, AE. SMMD. IV: 41/4676). 1681 tarihinde camide hatiplik yapan Salih Efendi bir senelik alacağını yine Boyahane Mukataası'ndan tahsil etmiştir (BOA, E. ML: 33/3212).1774 senesinde camide imam-1 sani olarak görev yapan el-Hac Ali Halife ise bir yıllık ücreti Trabzon Adet-i Ağnam Mukataas1 emvalinden karşılamıştır (BOA, AE. SABH. I: 326/22244; BOA, AE. SABH. I: 326/22243).

Camideki görevlilerin alacaklarının zaman zaman hazineden karşılandığı ile ilgili arşiv belgelerinde bazı ifadeler yer almakla birlikte bu konuda ihtilafın söz konusu olduğu görülmektedir. Örneğin Ekim 1898 tarihli yazıda Kanuni Sultan Süleyman Han Evkafi'ndan olup sonradan padişah iradesiyle tamir edilen Sultan Süleyman Han Cami hademesinin ücretlerinin Anadolu Vilayeti Müftüsü Şakir Paşa'nın talebi üzerine eskisi gibi hazineden ödenmesi talep edilmektedir (BOA, BEO: 1206/90415). Ancak arşiv belgeleri incelendiğinde bu konuyla ilgili ihtilafların devam ettiği anlaşılmaktadır. Nitekim Ekim 1898 tarihli belgede Sultan Süleyman Han Cami’nin, Kanuni Sultan Süleyman Hazretlerinin hayratlarından olup bir süreden beri harap olması nedeniyle daha önce irade ile gereği yerine getirilmiş olan Sultan Süleyman Han Cami hademesinin ödeneği olmadığından bahisle uygun miktar maaş ile görevlendirilmelerine dair caminin imam, hatip ve müezzini tarafından bir arzuhal verilmiştir. Bu talebin yerine getirilmesi üzerine Anadolu Vilayeti Müşiri Şakir Paşa hazretleri tarafından da daha önceden bu tahriratla birlikte talepte bulunulmuş ve bunun üzerine yapılan incelemede Sultan Süleyman Cami hademesinin ücretlerinin Canca nam-1 diğer Erzurum Mukataası emvalinden olmak üzere Maliye Hazinesi'nden ödendiği anlaşılmıştır. Bunun üzerine hademelerin ücretlerinin eskisi gibi Maliye Hazinesinden tahsis ve tesviye edilmesinin uygun olacağına dair Maliye Nezareti’ne yazı yazılmıştır. Maliye Nezareti'nden gelen yazıda ise camide Canca Mukataası'ndan olmak üzere fetihhanlık, aşırhanlık, devirhanlık ve maarifhanlık maaşlarının senelik 116,5 kuruş ile Hafız Ahmed Efendi, hitabet maaşı olarak senelik 22 kuruş ile Mahmud Efendi uhdelerine tevcih edildiği, hitabet görevinin ise 1865/66 tarihine kadar tesviye olunarak ondan sonra talep edilmemesi nedeniyle değerlendirmeler haricinde kaldığı anlaşılmış ise de caminin Sultan Süleyman hazretlerinin vakıfları arasında yer almasından dolayı hademelerin ücretlerinin Evkaf-1 Hümayun Hazinesi'nden ödenmesi talep edilmiştir. Ancak Evkaf-1 Hümayun Nezareti'nden bildirilen yazıda cami hademesine Evkaf-1 Hümayun Hazinesi tarafindan görev verilmesinin mümkün olmadığı çünkü cami hademesinin hizmetlerinin Evkaf-1 Hümayun Hazinesi'ne dâhil olmadığı bu nedenle de 
eskisi gibi Maliye Hazinesi tarafindan ödenmesi gerektiği bildirilmiştir (BOA, BEO: 1237/92760).

Sultan Süleyman Han Cami’nde görev yapan kişiler hakkında bazı arşiv belgelerinde kısmi bilgiler bulunmaktadır. Örneğin, 1767 senesinin hemen başında Sultan Süleyman Han Cami Vaizi Hacı Mustafa Efendi'nin vefat ettiği belirtilmektedir. Torul Kadısı Mahmud Efendi imzasıyla yazılan yazıda aylığı 3 akçe ile görev yapan Hac1 Mustafa Efendi'nin yerine vaizlik görevinin Hafız Ebubekir Efendi'ye verilmesi talep edilmektedir (BOA, AE. SMST. III: 371/29425). 1808 tarihli başka bir arşiv vesikasında boşta bulunan Sultan Süleyman Han Cami hitabetinin Abdullah Halife’ye tevcih olunduğu belirtilmektedir (BOA, HAT: 1499/18). 1823 tarihli belgede aylığ beş akçe ile Sultan Süleyman Han Cami mütevellisi olan Ahmed Efendi'den boşalan göreve aynı maaşla oğlu Mehmed Şakir Efendi'nin atandığı ve 1849 tarihinde ise Mehmed Şakir Efendi'ye berat-1 şerif tevcih edildiği ifade edilmektedir (BOA, EV. BRT,: 14/7).

20 Temmuz 1902 tarihli Sadaret Mektubi Kalemi’nden Maliye ve Evkaf-1 Hümayun nezaretlerine gönderilen yazıda Kanuni Sultan Süleyman Han'ın vakıflarından olan ve Gümüşhane Kasabası'nda bulunan Sultan Süleyman Han Cami'nde görev yapan hizmetlilerin vazifelerinin düzenlenmesine dair bir irade gönderildiği belirtilmektedir. Ancak yazıda iradenin üst yazı ekinde bulunduğu ifade edilmesine rağmen ekinde bu irade yoktur (BOA, BEO: 1888/141591).

\section{b. Caminin Tamiri}

Cami günümüze gelinceye kadar birçok onarımdan geçmiş hatta 19. yüzyılın sonlarında y1kılmaya yüz tuttuğundan yeniden inşa edilmiştir. Bu nedenle yeniden inşa ve onarımlar nedeniyle orijinal özelliklerinin bir bölümünü kaybetmiştir. Son olarak 2006 ve 2016 senelerinde yenileme çalışmaları yürütülmüştür. 2006 yılında gerçekleştirilen onarımda, caminin içi ve son cemaat yeri yenilenmiş, avlusuna tuvaletler ve gasilhane yaptırılmıştır (Yurttaş 2007: 61). 2016 tarihindeki yenileme çalışmalarında ise cami içi duvarlarda hat sanatıyla yazılar yazılırken, caminin tabanında bulunan ahşap kaldırılarak ısıtma sistemi ile birlikte beton dökülmüştür. İç kısımda bulunan sütunların ahşapla kaplandığı camide halılar yenilenmiş, minber ve mihrap değiştirilmiş, caminin ortasında bulunan mihrap, duvar ile birleştirilerek bütünlük sağlanmıştır. ${ }^{4}$

\footnotetext{
${ }^{4}$ http://www.gumuskoza.com.tr/sultan-suleyman-han-camii-yenilendi.html (24.04.2018)
} 
Caminin tamiriyle ilgili Başbakanlık Osmanlı Arşivi’nde farklı tarihlerde yapılan tamiratlara dair çok sayıda belgeye rastlamak mümkündür. Konuyla ilgili arşiv kayıtlarında yer alan bazı yazışmalar şunlardır:

2 Şubat 1856 tarihinde Gümüşhane Meclisi tarafından gönderilen mazbatada Sultan Süleyman Han Cami'nin yıkılmaya yüz tuttuğu, bu nedenle cemaatin aşırı derecede zorlandığı, yapılan keşifte 100.000 kuruş masrafla cami ve çevresindeki yapıların tamiratının gerçekleştirilebileceği, şimdi tamir edilmez ise ileride tamamen yıkılacağı, Gümüşhane kasabasının Ayasofyası konumunda olan bu caminin hiç olmazsa 50.000-60.000 kuruş gönderilirse elbirliğiyle onarımına başlanacağ belirtilmektedir (BOA, MVL: 296/26). Gümüşhane Meclisi tarafından gönderilen bu mazbata önce Meclis-i Vala'ya oradan da Evkaf-1 Hümayun Nezareti'ne havale edilmiştir. Evkaf-1 Hümayun Nezareti'nden gelen cevabi yazıda ise caminin tamirinin hayır işlerinden olduğu ancak caminin Kanuni Sultan Süleyman'ın Dersaadet ve başka yerlerde bulunan hayrat vakıfları idaresinde bulunmadı̆̆ gibi vakıf, varidat ve hizmet görevlerine dair hazine tarafından ayrılan herhangi bir kaydının olmadığı ifade edilmektedir. Yazıda bu nedenle bundan sonra icabına bakılmak üzere her şeyden önce caminin mahallinde vakıf ve varidatı var mıdır? Varsa ne tür şeylerdir ve şimdiye kadar yapılan tamirat ve hizmet görevleri ne taraftan karşılanmıştır? gibi soruların cevaplarının etraflıca araştırılması istenmektedir (BOA, A. MKT. UM: 223/18).

Mayıs 1862 tarihinde Gümüşhane'den Evkaf-1 Hümayun Nezareti'ne yazılan yazıda Sultan Süleyman Cami'nin tamir, onarım ve kuvvetlendirmesine dair talepte bulunulduğu anlaşılmaktadır (BOA, A. MKT. NZD: 388/91).

Ocak 1887 tarihinde Gümüşhane Mutasarrıflığı İdare Meclisi tarafindan yazılan mazbatada Sultan Süleyman Han Cami’nin yıkılmaya yüz tuttuğu, bu nedenle yeni baştan imar ve inşasına dair padişah tarafından irade verildiği ifade edilmektedir. Yazının devamında caminin resim ve haritası gereğince memur ve yardımsever ahalinin de yardımlarıyla kasabadaki Dere Cami, Küçük Cami ve Çarşı Cami ile birlikte yeni baştan inşa edildiği belirtilmektedir (BOA, Y. MTV: 107/24).

28 Eylül 1891 tarihinde Evkaf-1 Hümayun Nezareti'nden Sadaret’e yazılan yazıda Sultan Süleyman Han Caminin yeniden inşasıyla ilgili yapılan keşif gereği mecidi 19 kuruş hesabıyla 41.900 kuruş harcanarak yeniden inşa edilmesi ve inşaat tamamlandığında keşifnamesinin daha sonra Evkaf-1 Hümayun Nezareti'ne gönderilmesi, inşaatın yapımı esnasında mahalli Evkaf müdürü, meclisi-i idare azasından ve erbab-1 vukufdan birer kişinin de bulunması, inşaat masraflarının da 
padişah hazretlerinin kişisel hesabında bulunan 1 milyon 43.900 küsur kuruştan karşılanması talep edilmiştir. Evkaf-1 Hümayun Nezareti'nin bu teklifi Sadaret tarafından padişaha sunulduktan sonra kabul edilerek gereğinin yapılmasına karar verilmiştir (BOA, İ. ŞD: 111/6653).

Aralık 1899 senesinde Evkaf-ı Hümayun Nezareti’ne yazılan yazıda Sultan Süleyman Han Cami'nin 41.900 kuruş harcanarak yeniden inşası için mecidi 20 kuruş hesabıyla 17.631 kuruşun daha harcanmasına izin verilmesi istenmektedir. Sultan Süleyman Cami eskiden beri şamdanlar ile aydınlatılmış olduğu halde şamdanların bazıları kullanılamayacak derecede eskidiği, geri kalanlarıyla da caminin aydınlatılmasının mümkün olmadığı, bu nedenle eskisi değiştirilmek üzere 20 mum ve 1 petrol lambası yakılacak bir avize, hasır, tarih taşı, hat levhası satın alınarak gönderilmesi gerektiği ifade edilmektedir. Yazıda talep edilen eşyaların ölçüleri, uzunluğu, genişliği ve yüksekliğine dair gönderilmiş olan iki adet defterde yazılı vasıflara nazaran eşyalardan avize için 13.000, tarih taşı için 400, hat levhası için 2.200, hasır için 300 ve bunların mahalline nakli için 500 kuruş olmak üzere toplam 5.400 kuruş harcanması gerektiği belirtilmiştir. İnşaatın tamamlanması için harcanması zorunlu görülen yukarıda zikredilen 17.631 kuruştan akçe fark1 olan 881 kuruş 20 paranın çıkarılarak geri kalan 16.809,5 kuruş eşya için tahmin edilen 5.400 kuruşun ilavesiyle hepsinin toplamı 22.209,5 kuruş olduğu bildirilmektedir. Bu paranın mahalli hasılat vakfiyesinden olmak üzere geçen 1900 tarihli Evkaf-ı Hümayun Bütçesi'nden harcanmasına izin verilmesi talep edilmektedir. Yazının sonunda caminin yeniden inşasıyla ilgili 5 Aralık 1895 ve 24 Ağustos 1898 tarihli iki adet yazı yazıldığı ancak bu yazılarla ilgili padişahın herhangi bir iradesinin tebliğ edilmediği, bu nedenle de durumun bu kez Trabzon Vilayeti İdare Meclisi'nden mazbatayla tekid edildiği belirtilmektedir (BOA, İ. EV: 24/39).

Ağustos 1907 tarihli belgede ise caminin aydınlatma masrafları için Gümüşhane Mal Sandığı'ndan aylık 150 kuruşun ödenmesine dair izin talep edilmektedir (BOA, ŞD: 432/25).

Yukarıdaki belgelere bakıldığında Gümüşhane İdare Meclisi’nin caminin sorunlarıyla yakından ilgilendiği, aydınlatma gibi küçük maliyetli işlemleri mal sandığından karşılamaya çalıştığı, büyük tamiratlar söz konusu olduğunda ise Evkaf-1 Hümayun Nezareti'ne müracaat ederek tamirat masrafların karşılanması için girişimlerde bulunduğu anlaşılmaktadır. 


\section{2- $\quad$ Sultan Süleyman Han Cami Haziresi}

Cami haziresi, caminin doğusunda ve cami zeminin hemen altında bulunmaktadır. Hazire Erzurum kültür ve tabiat Varlıklarını Koruma Bölge Kurulu'nun 24.06.1989 Tarih ve 160 sayılı kararıyla tescil edilmiştir. Hazirede, 1800-1905 y1lları arasında vefat eden kişilere ait 10 adet mezar vardır (GKE 2016: 213). Hazirede yer alan mezarlardan bazıları kitabelerinden anlaşıldığı kadarıyla şunlardır: Es-Seyyid Mehmed kızı Mahbube Hatun (Ölüm tarihi 1800-1801/1215), Hüseyin oğlu Mustafa (Ölüm tarihi 1892-1893/1310), Şiran Kaymakamı Hafız Ahmed Rıza (Ölüm tarihi 1897), Mine hanım (Ölüm tarihi 1900-1901/1318), Gümüşhane muhasebecisi Rüşdi Efendinin Eşi Rukiyye Hanım (ölüm tarihi 1900-1901/1318), Kılınççı Hacı Hüseyin Efendi’nin kızı Hatice Hanım (Ölüm Tarihi 1902), Çalıkoğlu Süleyman Ağa’nın kızı Dursune Hanım (Ölüm Tarihi 1905)'dır.

Hazirede yer alan mezar taşlarından bazıları üçgen başlıklı, bazıları fes başlıklı, bazılarının başlıkları da güllerle süslüdür. Taşlardaki yazılar ise daha çok sülüs ve talikle yazılmıştır. Kitabelerin birçoğu bitki motifleriyle süslenmiştir. Mezarlardan bazıları sanduka üzerine oturtulmuştur. Ancak birçok mezarın taşları ve sandukaları bakımsızlıktan hasar görmüş durumdadır (Yüksel 1997: 107-122).

\section{3- Hacı Tahir Efendi Türbesi}

Türbe caminin kuzey doğusunda hazirenin ortasında yer almaktadır. Türbenin üç yönünde birer pencere bulunmaktadır. Kitabesinde anlaşıldığı kadarıyla Hacı Tahir Efendi'nin Mısır el-Ezher Medresesi'nde eğitim aldığı ve 1755-1834 tarihleri arasında yaşadığı anlaşılmaktadır. Ancak Hacı Tahir Efendi hakkında fazla bir bilgi bulunmamaktadır. Türbenin 19. yüzyılın ilk yarısında inşa edildiği ve hazirenin oluşmasında en etkili unsurlardan biri olduğu tahmin edilmektedir (Yurttaş 2007: 67).

Trabzon Kültür ve Tabiat Varlıklarını Koruma Bölge Kurulu’nun 01.11.2002 tarih ve 4587 sayılı kararıyla tescil edilen türbe 2016 tarihli Gümüşhane Kültür Envanteri'nde Mısırlıoğlu Türbesi olarak kayıtlıdır. Kültür envanterinde türbenin doğu cephesinde yer alan girişin, sivri kemerli olduğu, kemer nişinin düzgün kesme taştan yapıldığ1 belirtilmektedir (GKE 2016: 232). Türbe içinde iki adet sanduka bulunmaktadır. Bunlardan büyük olanı Hacı Tahir Efendi'ye, küçük olanı ise Tahir Efendi'nin yakınlarından birine aittir (Yurttaş 2007: 67). 


\section{4- $\quad$ Sultan Süleyman Han Medresesi}

Arşiv belgelerinden hareketle Sultan Süleyman Han Medresesi’nin durumu hakkında kesin ve net bilgilere ulaşmak mümkün değildir. Bununla birlikte medresenin 19. yüzyıldaki durumu hakkında bazı bilgilere ulaşmak mümkündür. Belgelere bakıldığında 19. yüzyılın ikinci yarısında medresede 10 dersliğin bulunduğu, 5 müderrisin görev yapmakta olduğu ve 176 öğrencinin eğitim gördüğü anlaşılmaktadır (BOA, MVL: 296/26; TVS 1888: 267; MUS 1321: 605-606). Ancak yüzy1lın sonlarına doğru medresenin oda sayısının azalarak 4'e düştüğü anlaşılmaktadır (BOA, Y. MTV: 107/24).

Ocak 1856 tarihli Sultan Süleyman Han Cami ile çevresinde bulunan medrese odalarının çok zamandan beri tamir göremediğgi için harabeye döndüğü, bu nedenle burada öğrenim gören talebelerin başka yerlere göç ettiği ifade edilmektedir. Caminin ve medreselerin bu durumunun Erzurum'dan bölgeye gelen Anadolu Ordu-yu Hümayun komutanlarından Rıza Efendi tarafından da görüldüğü belirtilen yazıda eğer camiyle birlikte bu medrese odalarının da tamir edilmemesi halinde artık tamirinin mümkün olmayarak tamamen harap olacağı belirtilmektedir (BOA, MVL: 296/26). Ocak 1887 tarihinde Gümüşhane Mutasarrıflığı İdare Meclisi tarafından yazılan yazıda yıkılmaya yüz tutan medreselerin yeni baştan imar ve inşasına dair padişah tarafından irade verildiği ve cami ile birlikte bitişiğinde bulunan medrese odalarının da yeniden inşa edildiği ifade edilmektedir (BOA, Y. MTV: 107/24).

Bazı belgelerde de medrese görev yapan müderrislerin durumları ile ilgili kısmi bilgilere ulaşılmaktadır. Örneğin 1887 tarihinde Gümüşhane Mutasarrıflığı İdare Meclisi tarafından yazılan yazıda medresede görev yapan müderrislere nısfi hisse müderrislik görevi için senelik 32 kuruş 20 para ödendiği ancak bu paranın yetmediği belirtilmektedir. Bundan dolayı müderrislik ve vaizlik görevleri için aylık 200 kuruş ödenmesi talep edilmektedir. Yazının devamında müderrislere ödenen maaşların yetersizliği nedeniyle gayet takvalı ve ilm-i ulemadan olan Hacı Raşid Efendi’nin Gümüşhane Kasabası'nda geçinemediği ve bu yüzden Kelkit Kazası dâhilinde bulunan Posus Köyü’nde ikamet etmek zorunda kaldığı ifade edilmektedir. Bu nedenle de medrese yeniden inşa edilse de burada okuyacak talebe kalmadığg vurgulanmaktadır (BOA, Y. MTV: 107/24).

Belgelerden medresede görev yapanların maaşlarının nereden karşılandığg ile ilgili bilgilere de ulaşılmaktadır. Belgelere bakıldığında müderrislerin maaşlarının daha çok Gümüşhane Mukataası'ndan karşılandı̆̆ı anlaşılmaktadır. Örneğin maaşı 40 akçe 
olan Hüseyin Efendi 1735 tarihindeki istihkakını Mukataa Emini el-Hac Sadullah Efendi'den tahsil etmiştir (BOC, AE. SMHD. I: 86/5862). 1740 tarihinde müderrislik yapan Hüseyin Efendi ise birikmiş olan ücretini bu tarihte Mukataa Emini Mehmed Ağa'dan almıştır (BOC, AE. SMHD. I: 103/7298).

\section{5- Sultan Süleyman Han Kütüphanesi}

Kütüphane, Sultan Süleyman Han Cami’nin bitişiğinde 1892 senesinin başlarında açılmıştır (GŞS, 3: 130-134, Saylan 2014: 180). Faaliyete geçmeden hemen önce kütüphaneye Erzincanî Hacı Fehmi Efendi adına Cel'i hatla yazılmış 30 adet Kur’an-1 Kerim bağışlanmış, 1892 senesinin Haziran ayında ise Gümüşhane mutasarrıfı Ahmed Rıfat Bey kütüphaneye matbu basılmış çok sayıda kitap hediye etmiştir (GŞS, 3: 130-134, Saylan 2014: 180). Ahmed Rıfat Bey’in hediye ettiği kitaplar şunlardır:

- 2 cilt Hafız-1 Şirazî Divânı'nın Şerhi Hafız-1 Şerh-i Suri

- 7 cilt Mesnevî-i Şerif Şerhleri Ankaravî

- 5 cilt Künhü’l Ahbar Tarihi

- 2 cilt Füsusü’l Hikem Tercümesi

- 2 cilt $(\ldots .$.

- 4 cilt Âlem Tarihi

- 1 cilt Hüsnî Terkimi

- 1 cilt Muhiddin-i Arabî Divânı

\section{6- $\quad$ Sultan Süleyman Han Cami Vakfi}

Vakıf, Sultan Süleyman Han Cami’nin ihtiyaçlarını karşılamak için kurulmuştur. 3 nolu Gümüşhane Şer’iyye Sicili’nden anlaşıldığına göre 20. yüzyıl başlarında Sancak Tahrirat Müdürü Nimet Haib bin Mustafa Âlim Efendi, vakfın mütevellisi olarak görev yapmıştır (GŞS, 3: 130-134, Saylan 2014: 180). Ancak günümüzde bu vakfa ait herhangi bir bilgi bulunmamaktadır.

\section{Sonuç}

Kasabanın kuruluşunda ve gelişiminde önemli bir rolü olan Sultan Süleyman Han Cami, çevresine yeni yapıların da inşa edilmeye başlamasıyla 19. yüzyıldan itibaren küçük bir külliye mahiyetini arz etmeye başlamıştır. Cami ve çevresindeki yapılar şehrin merkezinde olması ve halka ziyadesiyle hizmet vermesi nedeniyle 19. yüzyıl boyunca birkaç kez önemli onarımdan geçmiştir. Ancak yüzyılın sonlarına doğru şehrin yer değiştirmesi nedeniyle şehirdeki diğer yapılar gibi Sultan Süleyman Han 
Cami ve çevresindeki yapılar da kendi haline bırakılmıştır. Bu nedenle cami ve çevresindeki yapılar yıkılmaya yüz tutmuştur.

Aslında bu durum sadece Sultan Süleyman Han cami ve çevresindeki yapılarla ilgili de değildir. Terk edilen ve kendi haline bırakılan bu şirin kasabadan geriye 100 yıl gibi kısa bir sürede sadece sahipsiz binalar yı̆̆ını kalmıştır. Bölgenin simgelerinden biri olan ve gururla övündüğümüz bölge konaklarının çok azı günümüze ulaşabilmiştir. Günümüze ulaşabilen konaklar ise yıkılmak üzeredir. 19. yüzyılda Gümüşhane'nin sosyal hayatında çok önemli bir role sahip olan vakıfların birçoğu ise günümüze dahi ulaşamamıştır. Bugün sağlam olarak ayakta kalabilen en önemli yapının Süleymaniye Cami ve çevresindeki hazire ve türbe olduğunu söylemek mümkündür.

Günümüzde caminin şehrin kuruluşundaki önemi her sene düzenlenen bir dizi etkinlikle hatırlanmaktadır. 2009 yılından beri her yıl Gümüşhane Kültür ve Turizm Müdürlüğü tarafından Trabzon'daki Muhteşem Kanuni Sultan Süleyman Vakfi'nın da katılımlarıyla "Kanuni Günleri” düzenlenmektedir. Etkinlik genel olarak, mehter takımı eşliğinde Fuadiye Caddesi'nden Atatürk Caddesi'ni takip ederek Belediye Hizmet Binası önünde sona eren yürüyüşle başlamakta olup, Sultan Süleyman Han Cami önündeki konuşmalar, mehter takımı gösterisiyle devam etmektedir. Tören, katılımcılara Kanuni Pilavı ikramıyla da sona ermektedir.

\section{Kaynaklar}

\section{Arşiv Belgeleri}

BOA, A. MKT. MHM, No: 313/80, sene 03 Cemaziye’l-evvel 1281(4 Ekim 1864)

BOA, A. MKT. UM, No: 223/18, sene 25 Cemaziye'l-evvel 1272 (2 Şubat 1856)

BOA, A. MKT. NZD, No: 388/91, sene 29 Cemaziye'l-ahir 1278 (4 Mayıs 1862)

BOA, AE. SABH. I, No: 252/16886, sene 10 Cemaziye'l-evvel 1200 (11 Mart 1786)

BOA, AE. SABH. I, No: 352/24685, sene 30 Zilhicce 1093 (30 Aralık 1682)

BOA, AE. SMHD. I, No: 103/7298, sene 29 Rebiü’l-ahir 1153 (24 Temmuz 1740) 
BOA, AE. SMHD. I, No: 247/20167, sene 24 Rebiü’l-evvel 1158 (26 Nisan 1745)

BOA, AE. SMHD. I, No: 86/5862, sene 20 Muharrem 1148 (12 Haziran 1735)

BOA, AE. SMMD. IV, No:2/141, sene 20 Cemaziye'l-evvel 1092 (7 Haziran 1681)

BOA, AE. SMMD. IV, No: 19/2098, sene 17 Şevval 1085 (14 Ocak 1675)

BOA, AE. SMMD. IV, No: 41/4676, sene 20 Şevval 1085 (17 Ocak 1675)

BOA, AE. SABH. I, No:326/22243, sene 10 Safer 1197 (15 Ocak 1783)

BOA, AE. SAMD. III, No: 28/2646, sene 21 Receb 1115 (30 Kasim 1703)

BOA, AE. SMST. III, No: 371/29425, sene 10 Şaban 1180 (11 Ocak 1767)

BOA, AE. SABH. I, No: 326/22244, sene 10 Safer 1188 (22 Nisan 1774)

BOA, AE. SMMD. IV, No: 2/180, sene 06 Şevval 1092 (19 Ekim 1681)

BOA, AE. SMMD. IV, No: 2/184, sene 10 Şevval 1092 (23 Ekim 1681)

BOA, BEO, No: 1237/92760, sene 12 Cemaziye’l-evvel 1316 (28 Eylül 1898)

BOA, BEO, No: 1888/141591, sene 16 Rebiü’l-ahir 1320 (23 Temmuz 1902)

BOA, BEO, No: 1206/90415, sene 21 Cemaziye’l-evvel 1316 (2 Ekim 1898)

BOA, C. EV, No: 138/6865, sene 29 Zilhicce 1217 (22 Nisan 1803)

BOA, E. EV, No: 13/1524, sene 13 Cemaziye'l-evvel 1092 (31 May1s 1681)

BOA, E. EV, No: 16/1900, sene 04 Zilhicce 1076 (7 Haziran 1666)

BOA, E. ML, No: 33/3212, sene 14 Receb 1092 (30 Temmuz 1681)

BOA, EV. BRT, No: 14/7, sene 21 Rebiü'l-evvel 1239 (25 Kasım 1823)

BOA, EV. BRT, No: 58/13, sene 04 Receb 1259 (31 Temmuz 1843)

BOA, EV. BRT, No: 158/21, sene 26 Zilhicce 1278(24 Haziran 1862)

BOA, İ. ŞD, No: 111/6653, sene 10 Rebiü'l-evvel 1309 (14 Ekim 1891)

BOA, İ. EV, No: 24/39, sene 01 Zilhicce 1317 (2 Nisan 1900)

BOA, HAT, No: 1499/18, sene 29 Zilhicce 1222 (27 Şubat 1808)

BOA, MVL, No: 296/26, sene 6 Cemaziye’l-evvel 1272 (14 Ocak 1856)

BOA, ŞD, No: 148/16, sene 20 Rebiü’l-evvel 1320 (25 Eylül 1861) 
BOA, ŞD, No: 432/25, sene 25 Cemaziye’l-ahir 1325 (5 Ağustos 1907)

BOA, Y. MTV, No: 107/24, sene 23 Rebiü’l-ahir 1312 (19 Ocak 1887)

\section{Şer'iyye Sicilleri}

3 nolu Gümüşhane Şer’iyye Sicili.

\section{Salnameler}

Salname-i Nezaret-i Maarif-i Umumiyye (1321). İstanbul.

Salname-i Vilayet-i Trabzon (1305). İstanbul.

\section{Kitap ve Makaleler}

BOSTAN, Hanefi (2002). XV-XVI. Astrlarda Trabzon Sancă̆ı'nda Sosyal ve İktisadi Hayat, Ankara.

DÜZBAKAR, Ömer (2003). “Osmanlı Döneminde Mahalle ve İşlevleri”, U. Ü. Fen-Edebiyat Fakültesi Sosyal Bilimler Dergisi, Sayı: 5, s. 97-108.

ERGENÇ, Özer (1995). Osmanlı Klasik Dönemi Kent Tarihçiliğine Katkı (XVI. Yüzyılda Ankara ve Konya), Ankara Enstitüsü Vakfı Yayınları, Ankara.

ERGENÇ, Özer (2013). Şehir, Toplum, Devlet Osmanlı Tarihi Yazıları, Tarih Vakfı Yurt Yayınları, İstanbul.

FAROQHI, Suraiya (2011). Osmanlıda Kentler ve Kentliler, Çev. Neyyir Kalaycıŏglu, Tarih Vakfi Yurt Yayınları, İstanbul.

Gümüşhane Valiliği (1973). Cumhuriyetin 50. Yılında Gümüşhane, Ankara.

Gümüşhane Valiliği (1999). Cumhuriyetin 75. Yılında Gümüşhane, İstanbul.

Gümüşhane Valiliği (2016). Gümüşhane Kültür Envanteri, Gümüşhane İl Turizm Müdürlüğü Yayınları.

KARPUZ, Haşim (1991). "Gümüşhane Evlerinin Mimari Özellikleri”, Geçmişte ve Günümüzde Gümüşhane Sempozyumu Bildirileri (13-17 Haziran 1990), Ankara, s. 155-183.

SAN, Sabri Özcan (1991). "Gümüşhane Müstakil Sancağındaki Mahalleler, Aileler ( Efsaneler, Hikayeler)”, Geçmişte ve Günümüzde Gümüşhane Sempozyumu Bildirileri (13-17 Haziran 1990), Ankara, s. 119-140.

SAYLAN, Kemal (2014). Gümüşhane-İdari, Sosyal ve Ekonomik Tarih, Gümüşhane Üniversitesi Yayınları, İstanbul.

SAYLAN, Kemal (2016). "Süleymaniye-Daltaban Arasında Gümüşhane'nin Şehirleşme Süreci”, Geçmişten Günümüze Şehir ve Çocuk, C. I, Canik Belediyesi Kültür Yayınları, Samsun, s. 67-74. 
TUNCEL, Metin (1996). "Gümüşhane”, Türkiye Diyanet Vakfi İslam Ansiklopedisi, C. XIV, İstanbul, s. 275.

USLU, Gülyüz Akagün (1980). Gümüşhane Çevresinin Tarihi ve Sanat Eserleri, İstanbul.

USLU, Gülyüz Akagün (1991). “Gümüşhane'nin Tarihçesi ve Turisttik Değerleri”, Geçmişte ve Günümüzde Gümüşhane Sempozyumu Bildirileri (13-17 Haziran 1990) , Ankara, s. 141-153.

ÜÇÜNCÜOĞLU, Adnan Güngör (Trhsz), Torul-Kürtün Tarihi, Torul Belediyesi Yayınlar1, Trabzon.

YURTTAŞ, Hüseyin (2007). "Gümüşhane Süleymaniye (Ulu) Camii, Çeşmesi, Haziresi ve Hacı Tahir Efendi Türbesi”, Sanat Dergisi, Sayı: 12, s. 61-72.

YÜKSEL, Murat (1997). Gümüşhane Kitabeleri, Gümüşhane Valiliği Yayınları, İstanbul.

\section{Internet Siteleri}

https://www.haberler.com/gumushane-de-8-kanuni-gunleri-etkinligi-8415462haberi/ (24.04.2018)

http://www.gumuskoza.com.tr/sultan-suleyman-han-camii-yenilendi.html (24.04.2018) 
Kemal SAYLAN, “Gümüşhane'deki Osmanlı Dönemi Eserleri:

Sultan Süleyman Han Cami ve Çevresindeki Yapılara Dair”, Mavi Atlas, 6(2)/2018: 75-94.

\section{Ekler:}

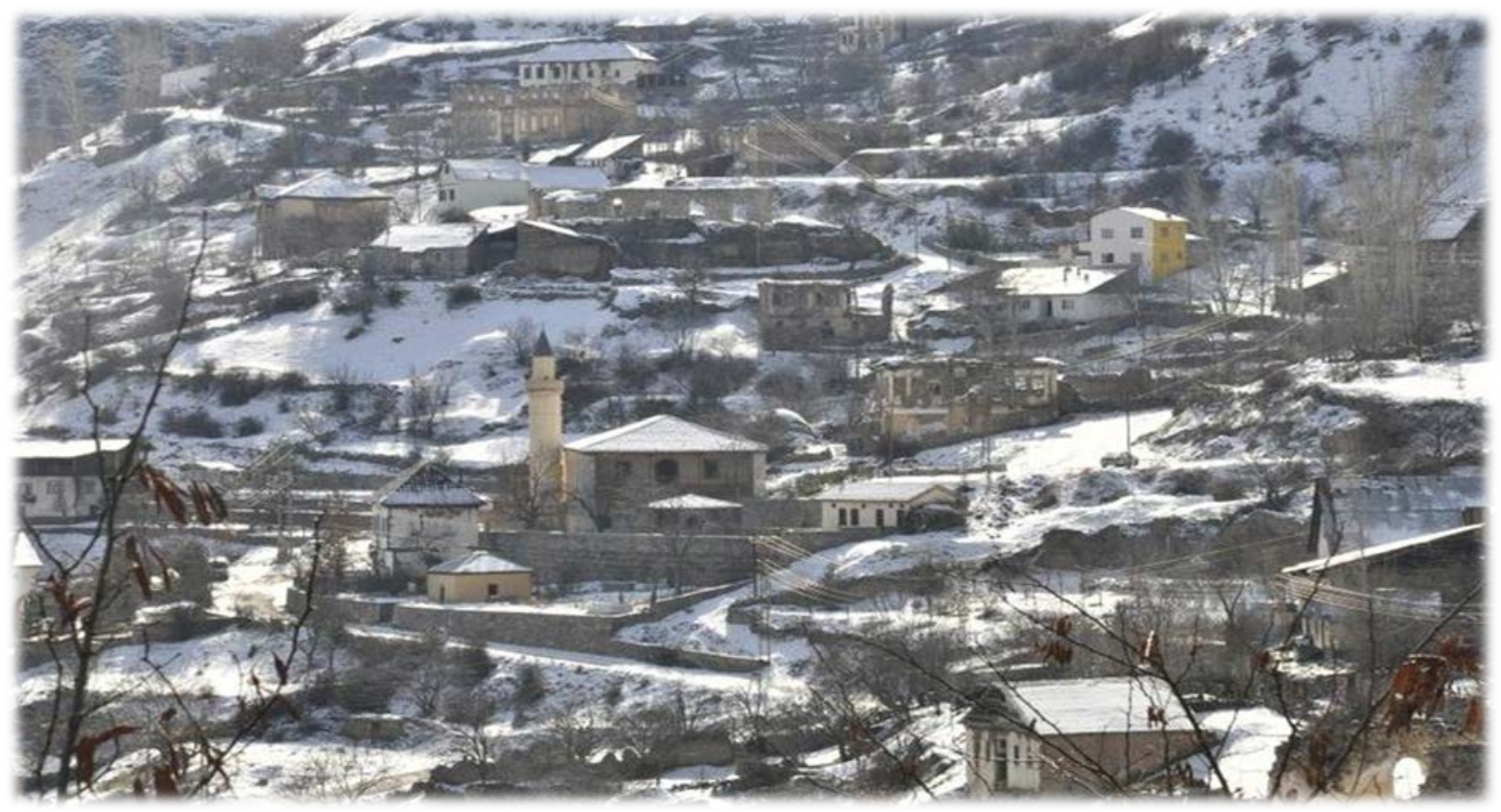

http://turizm.gumushane.edu.tr/tr/sayfa/gümüşhanede-turizm/süleymaniye-mahallesi-eski-gümüşhane (24.04.2018)

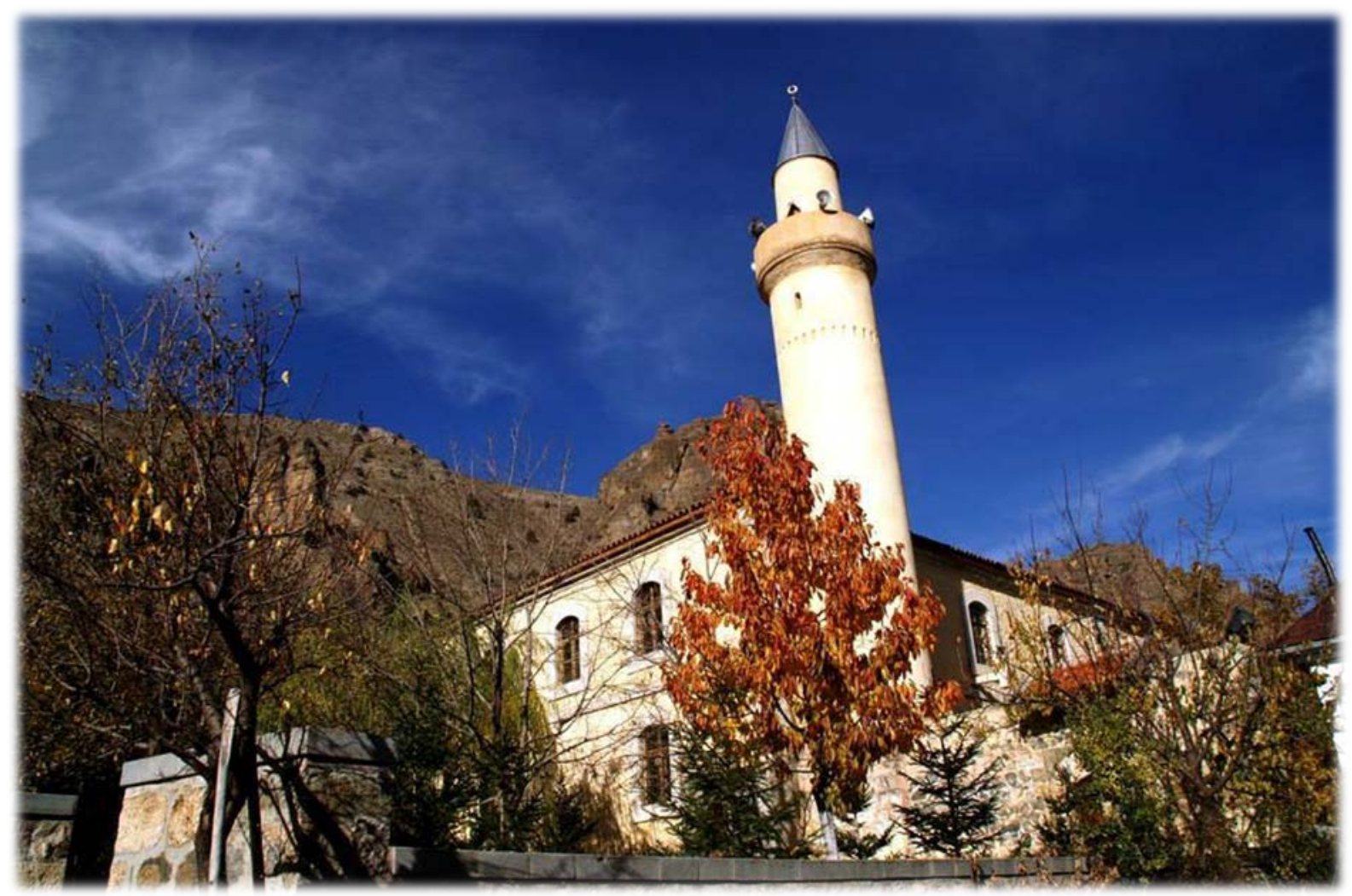

http://www.gumushane.gov.tr/suleymaniye-mahallesi (24.04.2018) 
Kemal SAYLAN, “Gümüşhane'deki Osmanlı Dönemi Eserleri:

Sultan Süleyman Han Cami ve Çevresindeki Yapılara Dair”, Mavi Atlas, 6(2)/2018: 75-94.

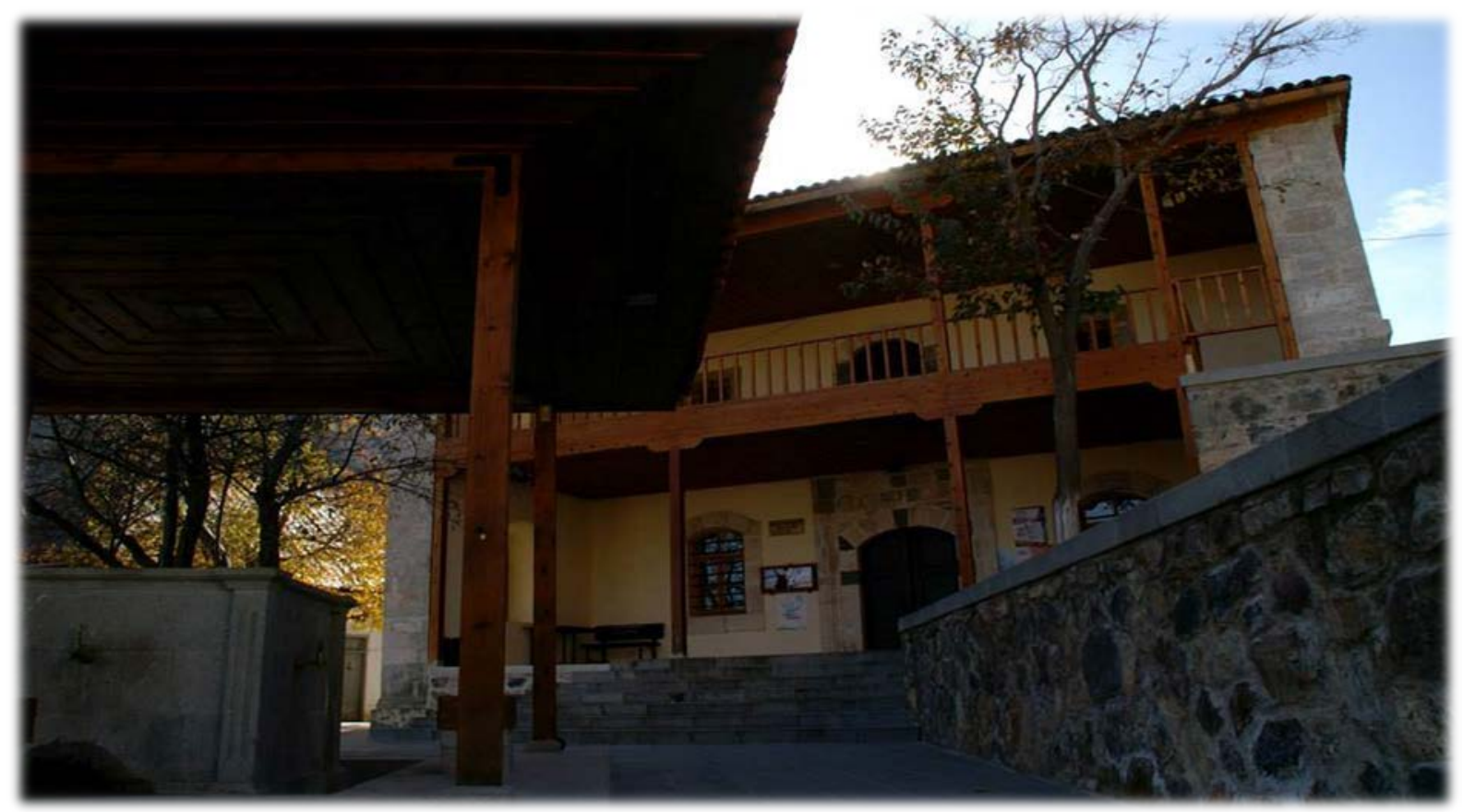

http://www.gumushane.gov.tr/suleymaniye-mahallesi (24.04.2018)
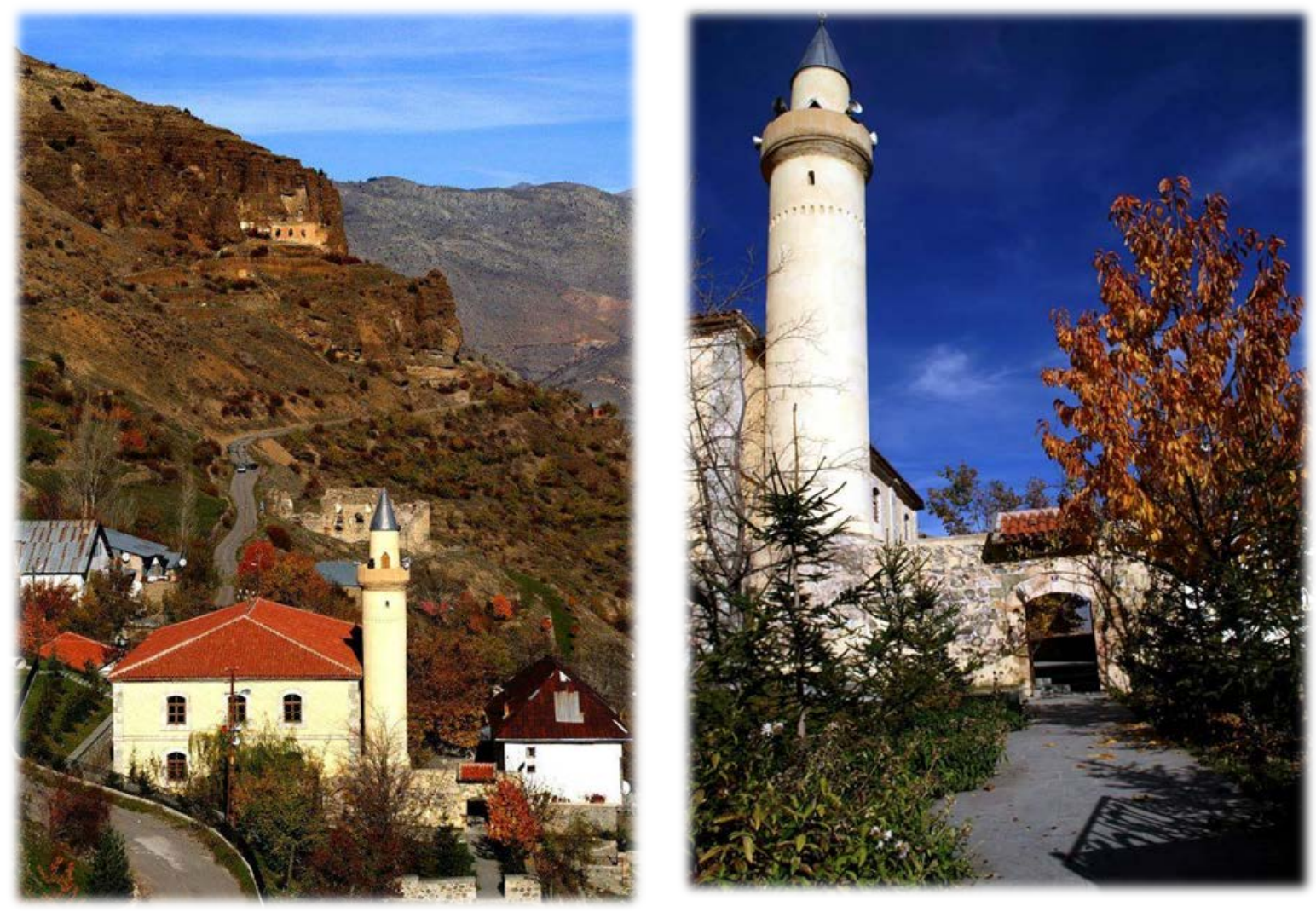

http://www.gumushane.gov.tr/suleymaniye-mahallesi (24.04.2018) 